\title{
BCL2 Overexpression Positive
}

National Cancer Institute

\section{Source}

National Cancer Institute. BCL2 Overexpression Positive. NCI Thesaurus. Code C153111.

An indication that overexpression of BCL2 has been detected in a sample. 